\title{
Guadalupe Amor y sus Décimas a Dios
}

F sta autora, que nos ha obsequiado con obras de tan importante valor literario y humano como Puerta obstinada (1947), Poesía (1948), y Polvo (1949), viene a darnos una especie de resumen de su sentír y de sus pensamientos, en estas décimas, tan contradictorias y al mismo tiempo tan simples. De sus primeros libros no hablaremos ahora; concentraremos nuestra atención en las Décimas a Dios.

De cuarenta y tres décimas consta este libro, y, característica que lo diferencia en gran manera de las otras obras de esta autora, tiene una introducción suya. La edición demuestra buen gusto $\mathrm{y}$ sencillez; y hay en todo el libro algo que atrae invenciblemente. Al mismo tiempo nos produce un vago malestar, un impaciente movimiento de fastidio a menudo. Pero nunca aburrimiento.

Cualidades y defectos son éstos que emanan de lo más profundo de la personalidad de la autora: una introvertida. Ella es una introvertida que quiere hacerse extrovertida, que quiere forzarse a comunicar al mundo exterior sentimientos que son intransmisibles; y que, aunque en su soberbia se crea la única poseedora de ellos, son patrimonio de toda aquella gran porción de la humanidad que vive "no sólo de pan".

$\mathrm{Y}$ he aquí que quizás hayamos acertado con la razón de nuestro fastidio al leer muchas de estas páginas. A la poetisä le falta humildad y humanidad, condiciones ambas que nuestros místicos, siendo más religiosos ¿ 0 , digamos, más dogmáticos?, no olvidabạn de manifestar en su poesía... Basta con leer las páginas iniciales de estas Décimas, en que la autora se nos muestra tal como es: llena de la importancia de sí misma, de su propio ser. Nos dice que desde niña no pudo hablar con sus padres, con sus hermanos ni con sus 
amigos como le hubiese gustado hablar a Dios. Poco después encontraremos en toda la obra que entre Dios y Guadalupe Amor (por supuesto nosotros, los demás mortales, no entramos en la cuenta) es Guadalupe Amor el ser más importante.

Esta introducción rebaja al libro, le llena de detalles que nos traen continuamente a la mente a la autora, la autora siempre, tratando de ponerse por encima de su obra, de hacer ver que es ella quien la ha escrito. Cuán verdaderas son sus palabras: "estoy llena de vanidad; de amor a mí misma." $Y$ se piensa inmediatamente en su frase: "He vivido mucho, pero he cavilado mucho más...".

No importa. Olvidémonos de las páginas preliminares y leamos los poemas. Guadalupe Amor es mujer inteligente en sumo grado, $\mathrm{y}$ ha escrito bellísimos poemas. En ellos, tanto como en la introducción, sentimos más que advertimos, la existencia de una oculta imitación a Sor Juana (y son parecidas las dos personalidades). ${ }^{1}$

Principia el libro con unos versos que nos dicen claramente el estado de duda, incertidumbre y desconfianza de la autora:

Dios, invención admirable.

E1 inventarte es posible.

Yo siempre vivo pensando cómo serás si es que existes.

Estado anímico bien conocido y mejor expresado. Necesidad de creer en momentos de amargura o desaliento; necesidad de una fe al sentirse débil. Como bien lo dice la autora en la introducción, sus versos oscilan desde la "fácil herejía hasta el impaciente misticismo". Nada extraordinarias son estas reacciones: ¿ no las sentimos todos al transcurrir nuestra vida - decepciones, alegrías, triunfos y fracasos?

Lo que sí nos sorprende en estos poemas es la simplicidad de su realismo, como filosofía aplicada a la forma literaria. Que es más sorprendente por ser tan complicada y poco real la esencia de los versos. Y que se transfunde extrañamente a la palabra, llenándonos de una representación plástica de lo evocado. Hay una extraña contradicción entre el tema y la manera como éste se halla presentado. A la poetisa le preocupa el aspecto físico, material, de Dios. Es decir, trata de aprehenderlo con sus manos, con sus ojos; de de- 
finirlo con palabras, de sentirlo con sus sentidos, por medio - podríamos decir- de instrumentos de precisión. Ella misma siente su falta $y$ to confiesa:

Dios mío, sé mi pecado consiste en verte en concreto.

$\mathrm{Y}$ en su incapacidad de elevarse hacia $\mathrm{El}$ y sintiéndose tan terrena (nos dice ella de su ser: “...que pensando con la frente / se está pudriendo en el lodo") pretende hacer que El descienda.

Esta necesidad de conocer la existencia de Dios en forma real y tangible, le impide encontrarlo:

no estás en todas las cosas

son invisibles tus huellas.

No, para Guadalupe Amor -realista y soñadora-, un árbol es un árbol, una rosa es una rosa, una nube es una nube... y nada más. Así pues, ¿ dónde está Dios? Si uno no lo lleva en sí, ¿ cómo encontrarlo en las cosas? De ahí su:

...estéril agonía

de conocer mi impotencia...

Algunos de sus poemas no son sinceramente incomprensibles en el profundo materialismo de su significado. $\mathrm{Y}$ pensando en sus otros libros mencionados en la primera página y en la tan acertada observación de A. Torres-Rioseco ${ }^{2}$ que dice: “...y aunque su visión poética es también de romántica naturaleza su movimiento sensorio está limitado por su afán de definición", nos preguntamos si no será que la autora - que, cerebralmente, es una idealista convencidano consigue nunca dominar ese fondo de materialismo profundo, o realismo si se quiere, que palpita latente muy dentro de ella:

$$
\begin{aligned}
& \text { y me da espanto mi suerte } \\
& \text { pues voy a morir sin verte } \\
& \text { y sin comprender tu esencia. }
\end{aligned}
$$

Pero su sinceridad es tan grande como su terrenidad. Sentimos simpatía por ella, nos identificamos en su sentir, cuando dice: 
Cuando débil soy, te imploro;

pero si me siento fuerte, yo soy quien hace la suerte.

Sinceridad tienen estas décimas; y verdad. Alma al desnudo, la autora no teme empequeñecerse (la mejor prueba de su orgullo). Reconoce su orgullo y su falta de fe, y la importancia que esto tiene en su vida; conoce lo vanos que son los esfuerzos de una mente: "pero a mi humano criterio / le está vedado volar", y sin embargo, el anhelo por algo mejor no la abandona. Anhelo es éste que es un valor positivo en sí mismo, aunque quizás nunca llegue a realizarse; anhelo de elevación espiritual, de engrandecimiento del alma.

Sí. No nos cabe duda que uno de los elementos que más valor dan a este libro es su profunda sinceridad. Sinceridad de mujer tan llena de sí misma que ha olvidado su propia pequeñez. Así, no puede evitar un constante enfocar a Dios desde su pequeñito mundo intelectual y emocional, presentándole sus problemas (iy reprochándole su falta de interés en ellos!). De tal modo que a veces nos da la impresión de estar leyendo a un autor medieval. Impresión que se refuerza al encontrar en estas décimas una serie de cándidas impertinencias que nos sorprenden y divierten; impertinente es, por cierto, la autora con todos (¿pues no nos dice que es fácil vivir como todos nosotros, mientras que ella investiga, se atormenta y no acepta el misterio?); pero son las impertinencias para con Dios las que nos causan el más divertido asombro:

$¿ Q u e ́$ intentas conmigo hallar?

¿Te sirvo de experimento?

¡Ya vuélvete, Dios, visible!

¿Qué pierdes con que te vea?

Mi Dios, te propongo un trato:

ique sin tardar me enamores!

Que se convierte en impresión francamente desagradable, en algunos momentos: 
Impertinencias de niña mimada son éstas, que no pueden menos de producir una caída de tono, después de los momentos de profunda elevación espiritual a que nos arrastran algunos de sus versos.

La poesía de Guadalupe Amor es poesía esencialmente no popular. $Y$ el público no tiene nada que ver con ella. Es poesía de un poeta para sí mismo, por sí mismo, de sí mismo. $Y$ como en sus libros anteriores, encontramos en éste la misma actitud de concentración en su mismo ser, de encierro, de envolverse en sí misma. Guadalupe Amor es egocéntrica y vanidosa: para ella, sólo ella existe. No es poetisa de muchedumbres, ni siquiera de minorías. Esto, que pudiera ser considerado por algunos como una crítica desfavorable a la artista, se ofrece solamente como un comentario objetivo, sin que consideremos que esta cualidad aumente o disminuya el valor de la obra de arte en sí.

Pero lo que sí da valor y calidad a su obra, es la nostalgia y la sinceridad de su experiencia vital, el realismo de este monólogo interior. Valor de intimidad que le quita a su obra el valor de la comunicabilidad y que refuerza el sentir de que no es ella autora para muchedumbres.

Aparte de esta cualidad hay otra en el libro, que nos produce una cierta perplejidad y nos impide acercarnos a su autora: el que la existencia de éste su poderoso realismo se halle opuesta a un deseo inmenso, sincero, tenaz, de espiritualidad. Anhelo espiritual, un casi misticismo, a no ser por esta contradicción que la aleja de él, ya que el místico aniquila la realidad a fuerza de creer. Este es su problema: el estado de plena conciencia que la domina constantemente, no llegando a alcanzar una sobreconciencia, es decir, una experiencia mística. $\mathrm{Y}$, ¿qué poesía, y poesía mística, puede existir sin la seguridad subconsciente de la existencia de un más allá?

Los aciertos de Guadalupe Amor son, a veces, magníficos, tales como cuando describe la soledad suya, de ser que no cree en nada, y dice:

Soledad sola poseo

opaca, hueca, infinita 
exacta descripción de esa soledad sin límites. $Y$ cuando al no poder captar a Dios, profiere, acertando en describir poderosamente su sentir :

\author{
No tengo nạda de ti, \\ ni tu sombra ni tú eco, \\ sólo un invisible hueco \\ de angustia dentro de mí.
}

Sincera angustia tiene la perplejidad de este atormentado indagar:

¿Tú inventaste el pensamiento?

0 , ¿̇es él el que te inventó?

Porque el problema es torturante, angustioso, desesperante. Sobre todo si al tratar de enfocarlo con la mente, como ella misma lo dice, se escapa la Idea — que es en realidad nervios y emoción-, para que sólo la vanidad sea la que soporte su" existencia. Y cuando Guadalupe Amor dice: "eres el eterno ausente / que de la angustia nació", recordamos a Aquel gran torturadó que pudo decir: "Dios mío, Dios mío, ¿ por qué me has abandonado?"

Quizás sorprenda a muchos encontrar como expresión de un alma complicada y retorcida en extremo, angustiada y palpitante, descontenta e inquietante, un vocabulario tan sencillo, tan directo, tan limitado si se quiere. Las palabras que usa la autora son las comunes, sin ninguna demostración de intelectualismo. $Y$ si en algún momento es su expresión rebuscada, lo es con una rebuscada sencillez:

Hoy Dios llegó a visitarme

y entró por todos mis poros.

De läs imágenes, cuando éstas se hallan presentes, lo que no es muy a menudo, se puede decir 10 mismo. Lo que de Sor Juana tiene Guadalupe Amor, como ya hizo notar Torres-Rioseco (ob cit.), que habla de "la absoluta sencillez" que persigue la poetisa, no son las imágenes poéticas rebuscadas, no es el conceptismo. Lo mismo se puede repetir del fluir límpido de su verso. Que fluye así, fácilmente, ligeramente, serenamente, por el don poético que debe ser 
patrimonio suyo, si tan tempranamente ha demostrado esta poetisa tal seguridad en el manejo de la rima.

$Y$ nos preguntamos: ¿es esta característica voluntaria en ella? ¿Ha perseguido ella la simplicidad, tratando de hacer de estas décimas una rudimentaria comunicación con Dios, en la que sólo se necesitan los signos más elementales, o existe en ella una definitiva pobreza de lenguaje, de expresión, de vocabulario, que se hace más visible al repetirse el tema, el personaje, la forma y el estilo en los poemas? Examinamos sus otros libros y encontramos la misma rebuscada sencillez en ellos, y repetimos rebuscada. Porque crêemos que Guadalupe Amor sigue un plan preconcebido en sus poemas: el de formarse un estilo nuevo, propio y único, que corresponda a su vigoroso individualismo. Y el mismo énfasis que pone en la elegante sencillez de sus versos, lo pondrá en escoger la misma elegancia en la presentación del libro, de todos sus libros, desde su forma hasta el tipo de imprenta y la calidad de papel en que están impresos, y el cuidar minucioso del detalle.

Al terminar la lectura de las Décimas a Dios sentimos, muy dentro de nosotros, que hay algo, más allá de -sus inseguridades y de sus impertinencias; algo que trata de manifestarse y que aún no ha encontrado su más adecuada expresión. Sincera es la búsqueda de la autora en el infinito, su lucha por convencerse de la existencia de un ser supremo, su tratar de explicarse a ese ser, para amarlo más y mejor. $\mathrm{Y}$ en este anheloso indagar suele obtener bellísimos efectos de contraposición de conceptos, como en aquella décima cuyo espíritu ha ido perdurando en nosotros a través de los siglos, desde aquel su comienzo en los acentos de la poesía provenzal. Y como en ella, sentimos la armonía de aquella búsqueda por:

el silencio sin tortura, la libertad en clausura, la fe sin exaltación.

Y reconocemos también el valor de síntesis de este libro. En unos cuantos versos pasa ante nuestros ojos la visión admirable del más profundo sentir y de los torturantes problemas de toda una existencia. Guadalupe Amor, en versos que a menudo poseen un pro- 
fundo valor estético, nos muestra su difícil lucha por la obtención completa e irrefutable de la verdad que busca. Sabemos que la lucha 1ha sido dura, y fué privilegio nuestro dejarnos llevar por ella en su atormentada senda.

Mtreya Jaimes Freyre, University of California, Berkeley.

\section{N O T A S}

1 A propósito de esta semejanza, véase A. Torres-Rioseco, Concepto de una nueva poesía, en el suplemento de El Nacional, marzo de 1947. México.

2 A. Torres-Rioseco, ibid., y también del mismo autor, para una crítica de la obra de Guadalupe Amor, véase "Puerta obstinađa", en el suplemento de El Nacional, 1947. 